\title{
An Autopsy Case of POEMS Syndrome with a High Level of IL-6 and VEGF in the Serum and Ascitic Fluid
}

\author{
Shin Minamitani, Satoko Ohfuj, Shuhei Nishiguchi, Susumu Shiomi, Masayuki Ogami*, \\ Toshihiko Matsuo*, Masahiko Ohsawa*, Kensuke OhtA** and Masayuki Hino**
}

\begin{abstract}
A 45-year-old woman was hospitalized because of systemic edema and peripheral nerve impairment. The patient had complications of organomegaly, endocrinopathy, and monoclonal gammmopathy, and was diagnosed with POEMS syndrome based on these characteristic signs and symptoms. Interleukin-6 (IL-6) and vascular endothelial growth factor (VEGF) levels in the serum and ascitic fluid were high. Many of the patient's symptoms were ameliorated, and IL-6 and VEGF levels in the serum and ascitic fluid decreased slightly during chemotherapy, but she died of respiratory failure. Autopsy revealed severe systemic edema and macroscopic hemorrhage in many organs, but VEGF and IL-6 producing cells were not found.

(Internal Medicine 41: 233-236, 2002)
\end{abstract}

Key words: Crow-Fukase syndrome, chemotherapy, cytokine

\section{Introduction}

POEMS syndrome is a rare multisystem disorder first described by Crow in 1956. It is characterized by polyneuropathy, organomegaly, endocrinopathy, monoclonal gammmopathy, and skin changes. In previous reports, it is proposed to be associated with a high level of interleukin-6 (IL-6) or vascular endothelial growth factor (VEGF). We report a patient with POEMS syndrome with high levels of IL-6 and VEGF in the serum and ascitic fluid. Treatment improved the patient's condition and decreased the levels of these cytokines.

\section{Case Report}

A 45-year-old woman was admitted to our hospital because of mild dyspnea on exertion, feeling of fullness in the abdomen, and glove-and-stocking type sensory impairment in April
1999. The patient had a history of admission in a nearby hospital for severe dyspnea in 1997, and was diagnosed with hypertensive heart disease and hypothyroidism. Mild edema in the lower extremities sometimes appeared from then on, but was controlled with diuretic drugs.

On admission to our hospital, body temperature was $37.5^{\circ} \mathrm{C}$, blood pressure was $108 / 40 \mathrm{mmHg}$, and pulse was 64 beats per minute with a regular rhythm. Moderate hepatomegaly, bilateral pretibial edema, and massive ascites were found, and some lymph nodes with a diameter of up to $1.5 \mathrm{~cm}$ were palpable in the bilateral cervical, axillary and inguinal regions. The lower tendon reflexes were absent, and pin-prick, touch, vibration, temperature, and position sensation of extremities were decreased. Skin pigmentation was not found. As shown in Table 1 , slight anemia, severe hypoproteinemia, and renal function abnormality were seen. Serum $\operatorname{IgA}$ level was high and there was a $\gamma$-globulin M-peak in the protein fraction which was confirmed to be IgA- $\lambda$ monoclonal protein by immunoelectrophoresis, though there were no remarkable findings except for a mild increase in plasma cell number on bone marrow aspiration examination. Biopsy of the left inguinal lymph node showed that plasmacytoma was not found and there were no remarkable findings except for moderate lymphocyte infiltration in the intrafollicular space (Fig. 1). Mild proteinuria was observed, but occult blood and Bence-Jones protein were not detected in the urine. Endocrinological study showed that the patient was in a mild hypothyroid state. The ascites was clear and a slightly yellow color. Though the ascites was exudative, no malignant cells were found on cytologic diagnosis and no bacteria were found by stab culture. IL-6 and VEGF levels were high in both the serum and ascitic fluid. Chest X-ray examination and echocardiography revealed slight pleural effusion and pericardial effusion, but there were no signs of cardiac failure. Abdominal CT scan and abdominal ultrasonography revealed hepatosplenomegaly, para-aortic lymphadenoma, and massive ascites. There was no abnormal accumulation of radioisotope anywhere in the body on ${ }^{67} \mathrm{Ga}$-citrate scintigraphy. The conduction velocity of peripheral nerves we studied was reduced

From the Department of Hepatology, *the Department of Pathology, and **the Department of Clinıcal Hematology, Graduate School of Medıcıne Osaka City University, Osaka

Received for publication June 27, 2001; Accepted for publication November 4, 2001

Reprint requests should be addressed to Dr. Shın Minamıtanı, the Department of Hepatology, Graduate School of Medıcıne Osaka City Unıversıty, 1-4-3 Asahımachi, Abeno-ku, Osaka 545-8585 
Table 1. Laboratory Data on Admission

\begin{tabular}{|c|c|c|c|c|c|}
\hline $\mathrm{CBC}$ & & Blood chemistry & & Immunoelectrophoresis & \\
\hline WBC & $6,100 / \mu 1$ & $\mathrm{TP}$ & $5.7 \mathrm{~g} / \mathrm{dl}$ & IgA- $\lambda$ type M-bow & $(+)$ \\
\hline Bas & $2 \%$ & Alb & $2.9 \mathrm{~g} / \mathrm{dl}$ & & \\
\hline Eos & $1 \%$ & T-Bil & $0.5 \mathrm{mg} / \mathrm{dl}$ & & \\
\hline St & $7 \%$ & AST & $7 \mathrm{IU} / l$ & Urine & \\
\hline Seg & $72 \%$ & ALT & $2 \mathrm{IU} / l$ & protein & $(+)$ \\
\hline Ly & $8 \%$ & ALP & $136 \mathrm{IU} / l$ & sugar & $(-)$ \\
\hline Mono & $10 \%$ & $\mathrm{CHE}$ & $110 \mathrm{IU} / \mathrm{l}$ & occult blood & $(-)$ \\
\hline Plasma & $0 \%$ & LDH & $179 \mathrm{IU} / l$ & BJP & $(-)$ \\
\hline $\mathrm{RBC}$ & $378 \times 10^{4} / \mu \mathrm{l}$ & LAP & $33 \mathrm{IU} / l$ & & \\
\hline $\mathrm{Hb}$ & $9.9 \mathrm{~g} / \mathrm{dl}$ & $\gamma$-GTP & $22 \mathrm{IU} / \mathrm{l}$ & Ascites & \\
\hline $\mathrm{Ht}$ & $30.8 \%$ & BUN & $68 \mathrm{mg} / \mathrm{dl}$ & specific gravity & 1.02 \\
\hline \multirow[t]{2}{*}{ Platelet } & $30.8 \times 10^{4} / \mu 1$ & Cre & $3.3 \mathrm{mg} / \mathrm{dl}$ & protein & $3.2 \mathrm{~g} / \mathrm{dl}$ \\
\hline & & CRP & $0.6 \mathrm{mg} / \mathrm{dl}$ & Rivalta reaction & $(+)$ \\
\hline Tumor marker & & IgG & $1,210 \mathrm{mg} / \mathrm{dl}$ & cell count & $150 / \mu 1$ \\
\hline AFP & $3.3 \mathrm{ng} / \mathrm{ml}$ & $\operatorname{IgA}$ & $507 \mathrm{mg} / \mathrm{dl}$ & mononuclear cell & $67 \%$ \\
\hline \multirow[t]{6}{*}{ CEA } & $<0.5 \mathrm{ng} / \mathrm{ml}$ & IgM & $112 \mathrm{mg} / \mathrm{dl}$ & multinuclear cell & $33 \%$ \\
\hline & & FT3 & $1.3 \mathrm{pg} / \mathrm{ml}$ & IL-6 & $2,330 \mathrm{pg} / \mathrm{ml}$ \\
\hline & & FT4 & $0.7 \mathrm{ng} / \mathrm{dl}$ & VEGF & $674 \mathrm{pg} / \mathrm{ml}$ \\
\hline & & $\mathrm{TSH}$ & $8.49 \mu \mathrm{IU} / \mathrm{ml}$ & & \\
\hline & & IL-6 & $15.6 \mathrm{pg} / \mathrm{ml}$ & & \\
\hline & & VEGF & $320 \mathrm{pg} / \mathrm{ml}$ & & \\
\hline
\end{tabular}

AFP: alpha-fetoprotein, BJP: Bence-Jones protein, CEA: carcinoembryonic antigen, IL-6: interleukin-6, VEGF: vascular endothelial growth factor.

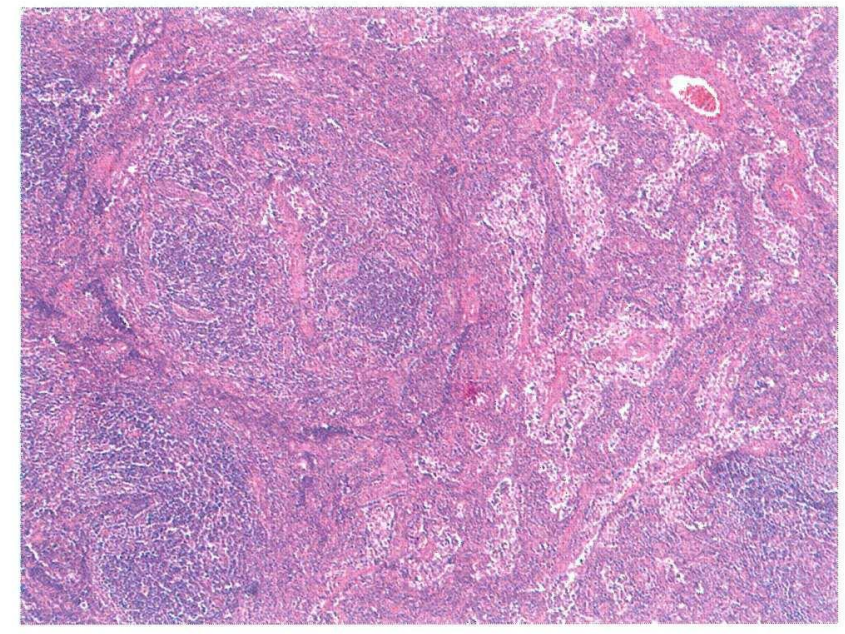

Figure 1. In the biopsy specimen of the left inguinal lymph node, no plasmacytoma was found and there were no remarkable findings except for moderate lymphocyte infiltration in the intrafollicular space (HE stain, $\times 100$ ).

in both motor and sensory components (Table 2).

The patient was diagnosed with POEMS syndrome based on the above findings. The clinical course of the patient from admission is shown in Fig. 2. Serum IgA level fell and many of the patient's symptoms remitted following treatment with steroid, but edema and ascites gradually worsened again. The pa- tient therefore received additional treatment with cyclophosphamide and vincristine. This combination chemotherapy led to clinical improvement with temporary resolution of edema and ascites. IL- 6 and VEGF levels were slightly decreased by chemotherapy. However, the patient's respiratory state worsened because of pulmonary edema and she died of respiratory failure on the forty-ninth day after admission.

\section{Pathological findings}

Autopsy revealed severe edema systemically and in multiple organs (bilateral lungs, liver, heart and bilateral kidneys). Pleural effusion (right: $500 \mathrm{ml}$, left: $600 \mathrm{ml}$ ), ascites (3,000 $\mathrm{ml}$ ), and massive pulmonary hemorrhage (right: $900 \mathrm{~g}$, left: $775 \mathrm{~g}$ ) were found. The mucous membrane of the gastrointestinal tract was edematous, and there was macroscopic hemorrhage. No swelling was found in lymph nodes of para-aorta, bifurcation of trachea, and hilum of lung. Microscopically, obvious plasmacytoma was not found in the bone marrow and lymph nodes of the bifurcation of trachea, para-aorta, and hilum of lung. Also, histological findings revealed that occasional plasma cells and few Russell bodies were found, and lymphocytes were dominant in the intrafollicular space of lymph nodes of bifurcation of trachea, para-aorta, and hilum of lung. Moreover, immunohistochemical staining using monoclonal antibody of VEGF (Santa Cruz) and polyclonal antibody of IL-6 (Endogen) $(1,2)$ in the lymph node biopsy specimen before death and lymph nodes of bifurcation of trachea, para-aorta, and hilum of lung in autopsy were performed. VEGF positive cells were found in occasional macrophages, but IL-6 positive 
An Autopsy Case of POEMS Syndrome

Table 2. Peripheral Nerve Conduction Velocity

\begin{tabular}{lccc}
\hline & Right median nerve & Right ulnar nerve & Right tibial nerve \\
\hline Motor component & 36 & 34 & 24 \\
Sensory component & 37 & 36 & 27 \\
\hline
\end{tabular}

$(\mathrm{m} / \mathrm{s})$

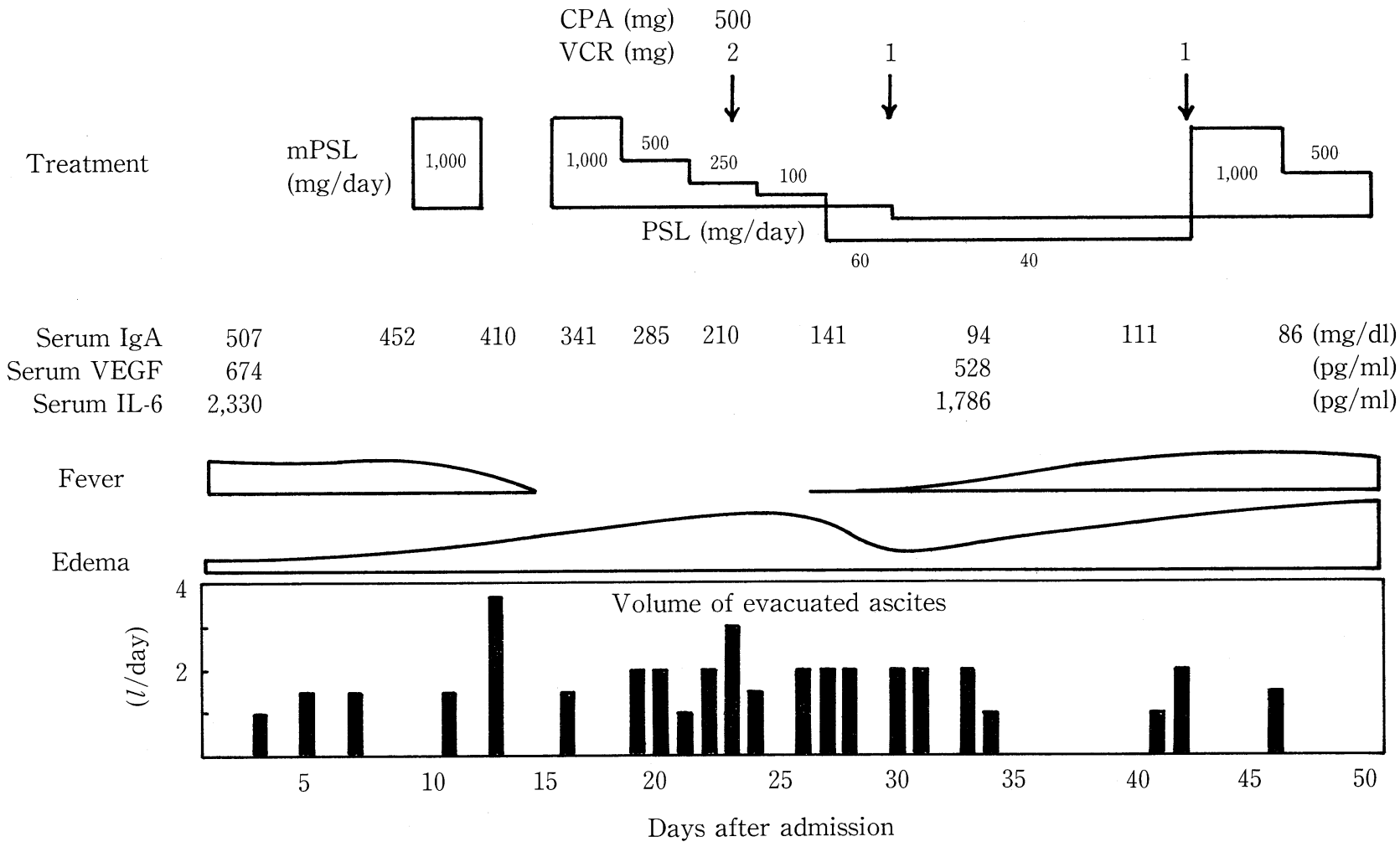

Figure 2. The clinical course of this patient from admission. CPA: cyclophosphamide, IgA: immunoglobulin A, IL-6: interleukin6, mPSL: methylprednisolone, PSL: prednisolone, VCR: vincristine, VEGF: vascular endothelial growth factor.

cells were not found in any of the specimens. Membranoproliferative glomerulonephritis bilaterally in the kidneys, cytomegalo-virus infection in the left lung, colon, adrenal gland and ovary, and herpetic esophagitis were also found.

\section{Discussion}

A unique syndrome with various clinical symptoms, which was first reported by Crow in 1956, is called POEMS syndrome (3). The first Japanese patient with clinical features similar to this syndrome was reported by Fukase et al in 1968 (4), and POEMS syndrome has therefore also been called Crow-Fukase syndrome (5). Though POEMS syndrome is more common in Japan and 165 patients were reported from 1968 to 1991 (6), the mechanisms responsible for its various clinical manifesta- tions are unknown. It has recently been speculated that a high level of serum IL-6 (7-9) or VEGF (10-12) is responsible for many symptoms of POEMS syndrome. VEGF is known as a vascular permeability factor, and has a strong effect of acceleration of vasopermeability. The characteristic features of POEMS syndrome such as edema, ascites, polyneuropathy, and organomegaly may be induced by an increase in serum VEGF level. Serum IL-6 level was reported to be a useful marker for predicting exacerbation of POEMS syndrome (13). It is not yet known which type of cell secretes these cytokines, but it may be associated with an outgrowth of plasma cells since POEMS syndrome is often accompanied by plasmacytoma (14 16).

The present patient had many characteristic signs and symptoms of POEMS syndrome. VEGF and IL-6 levels in the se- 
rum and ascitic fluid were high, but obvious plasmacytoma and high level of VEGF and IL-6 producing cells were not found in lymph nodes or other organs by autopsy. In addition, histological findings of lymph nodes indicated no evidence of other lymphadenopathy e.g., Castleman's disease.

The clinical course of POEMS syndrome is chronic in many cases, and some patients have survived for more than 10 years after onset. The most effective treatment of POEMS syndrome is excision of plasmacytoma, if it is present. It has been reported that eighty-three percent of patients with POEMS syndrome who were treated by excision of plasmacytoma experienced clinical improvement. Localized irradiation for plasmacytoma is also effective, and it has been reported that seventyfive percent of patients who were treated by radiotherapy achieved clinical improvement. It has been reported that the efficacy of chemotherapy is inferior to that of excision of plasmacytoma or radiotherapy (6). We performed chemotherapy because we could not detect plasmacytoma in our patient. Melphalan and steroid are often used to treat patients with POEMS syndrome, and cyclophosphamide and vincristine are sometimes used as well $(5-8,17)$. We could not use melphalan, an oral drug, because bleeding from the gastrointestinal tract had occurred prior to treatment in our patient. We therefore used cyclophosphamide and vincristine, which are intravenous drugs. The combination chemotherapy that our patient received was effective, since many of her signs and symptoms, such as edema of the extremities and ascites, were temporarily ameliorated. IL-6 and VEGF levels decreased slightly during chemotherapy. However, chemotherapy did not improve the respiratory state of our patient. It has been reported that many patients with POEMS syndrome die not of plasmacytoma but of anasarca, and in particular of respiratory failure due to pulmonary edema $(16,18)$. Our patient died of this condition, as well. We may be able to help more patients with POEMS syndrome when drugs that better inhibit the vasopermeability of VEGF are developed.

\section{References}

1) Gomez-Guerrero C, Lopez-Armada MJ, Gonzalez E, Egido J. Soluble IgA and IgG aggregates are catabolized by cultured rat mesangial cells and induce production of TNF-alpha and IL-6, and proliferation. $J$
Immunol 153: 5247-5255, 1994.

2) Lappin DF, MacLeod CP, Kerr A, Mitchell T, Kinane DF. Anti-inflammatory cytokine IL-10 and T cell cytokine profile in periodontitis granulation tissue. Clin Exp Immunol 123: 294-300, 2001.

3) Crow RS. Peripheral neuritis in myelomatosis. Br Med J 2: 802-804, 1956.

4) Fukumasu H, Nishitani H, Fukase M, et al. Solitary plasmacytoma with polyneuritis and endocrine disturbances. Nippon Rinsho 26: 2444-2456, 1968 (in Jananese).

5) Nakanishi T, Sobue I, Toyokura Y, et al. The Crow-Fukase syndrome: a study of 102 cases in Japan. Neurology 34: 712-720, 1984.

6) Takatsuki K, Matsuzaki H. Japanese clinical statistical data of patients with plasma cell dyscrasia with polyneuropathy and endocrine disorder. Nippon Rinsho 50 Suppl: 855-863, 1992 (in Jananese).

7) Mandler RN, Kerrigan DP, Smart J, Kuis W, Villiger P, Lotz M. Castleman's disease in POEMS syndrome with elevated interleukin-6. Cancer 69: 2697-2703, 1992.

8) Nakazawa K, Itoh N, Shigematsu H, Koh CS. An autopsy case of CrowFukase (POEMS) syndrome with a high level of IL-6 in the ascites. Acta Pathol Jpn 42: 651-656, 1992.

9) Bova G, Pasqui AL, Saletti M, Bruni F, Auteri A. POEMS syndrome with vascular lesions: a role for interleukin-1 beta and interleukin-6 increase -a case report. Angiology 49: 937-940, 1998.

10) Watanabe $O$, Arimura K, Kitajima I, Osame M, Maruyama I. Greatly raised vascular endothelial growth factor (VEGF) in POEMS syndrome. Lancet 347: 702, 1996 (letter).

11) Arimura $\mathrm{H}$, Watanabe $\mathrm{O}$, Arimura $\mathrm{K}$, Maruyama I, Hokezu $Y$. Two cases of POEMS syndrome with increased vascular endothelial growth factor (VEGF). Rinsho Shinkeigaku (Clin Neurol) 37: 817-823, 1997 (in Japanese, Abstract in English).

12) Watanabe $O$, Maruyama I, Arimura $K$, et al. Overproduction of vascular endothelial growth factor/vascular permeability factor is causative in CrowFukase (POEMS) syndrome. Muscle Nerve 21: 1390-1397, 1998.

13) Hitoshi $S$, Sato K, Suzuki K, Sato K, Sakuta M. The role of interleukin-6 in Crow-Fukase syndrome. Rinsho Shinkeigaku (Clin Neurol) 32: 577582, 1992 (in Japanese, Abstract in English).

14) Sakemi H, Okada H. An autopsy case of Crow-Fukase syndrome which developed 18 years after the first manifestation of plasmacytoma. Intern Med 31: 50-54, 1992.

15) Soubrier MJ, Dubost JJ, Sauvezie BJ. PCEMS syndrome: a study of 25 cases and a review of the literature. Am J Med 97: 543-553, 1994.

16) Hitoshi S. Crow-Fukase syndrome. Nippon Rinsho 53: 747-751, 1995 (in Japanese, Abstract in English).

17) Inoue $T$, Ohta $K$, Ohhira $H$, et al. Juvenile Crow-Fukase syndrome with response to bolus of methylprednisolone after failure of treatment by plasma exchange. Rinsho Ketsueki (Jpn J Clin Hematol) 31: 448-451, 1990 (in Japanese, Abstract in English).

18) Takatsuki K, Sanada I. Plasma cell dyscrasia with polyneuropathy and endocrine disorder: clinical and laboratory features of 109 reported cases. Jpn J Clin Oncol 13: 543-556, 1983. 